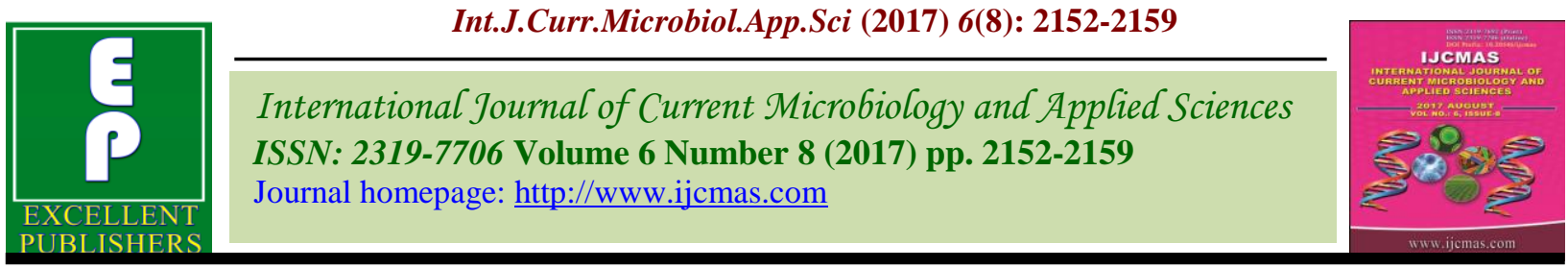

Review Article

https://doi.org/10.20546/ijcmas.2017.608.255

\title{
Growth Regulators for Yield and Quality Enhancement in Litchi (Litchi chinensis L) - A Review
}

\author{
Rachna Arora* and Nav Prem Singh
}

Department of Fruit Science, Punjab Agricultural University, Ludhiana-141004, India

*Corresponding author

\begin{tabular}{|c|c|}
\hline & A B S T R A C T \\
\hline $\begin{array}{l}\text { K e y w o r d s } \\
\text { PGRs, Litchi, } \\
\text { Fruit yield, } \\
\text { Improvement, } \\
\text { Fruit quality etc. }\end{array}$ & \multirow{3}{*}{$\begin{array}{l}\text { The basic and strategic research programs in litchi aim at developing technologies for } \\
\text { enhancing productivity, quality, facilitating processing and value addition for increased net } \\
\text { returns. The present literature has been, therefore, reviewed to clear the concepts and } \\
\text { approaches involving the use of PGRs paving way for future litchi production. } \\
\text { Physiological changes such as heavy fruit drop or early abscission in litchi might be due to } \\
\text { the lack of hormones needed for the embryo and fruit development, lack of pollination } \\
\text { and/or fertilization etc. Alteration of harvesting period in litchi may prolong the marketing } \\
\text { period and application of suitable plant growth regulators may help in achieving it The } \\
\text { emphasis need to be given to the action mechanism of these on litchi at various stages of } \\
\text { growth, development and storage as it has not been fully exploited for the improvement in } \\
\text { fruit yield and quality attributes in Indian conditions. }\end{array}$} \\
\hline Article Info & \\
\hline $\begin{array}{l}\text { Accepted: } \\
\text { 19 June } 2017 \\
\text { Available Online: } \\
10 \text { August } 2017\end{array}$ & \\
\hline
\end{tabular}

\section{Introduction}

Despite long history of litchi cultivation and its popularity both in domestic and international markets, many areas are experiencing low productivity due to a number of factors such as warm weather at flowering, unsuitable cultivars, improper tree management etc.

The existing gaps in yield potential, production of poor quality, un-attractive fruits and negligible export potential of quality litchi fruit are the main concerns. These need to be combated in modern day fruit production to meet the ever increasing demand to nourish the growing population and increasing the economic returns.
Plant growth hormones play important role in the integrated developmental activities of the fruits, yield as well as quality. Exogenous application of plant bio regulators in small quantities has become an important component for inhibiting or modifying the physiological processes by replacing or supplementing the endogenous hormones when their levels are below than required to bring a positive change in the course of plant development, thereby regulating different aspects such as fruit drop, quality and yield. Keeping all these factors in consideration, the present literature has been reviewed to clear the concepts and approaches involved with the use of different PGRs in relation to litchi fruit growth, development, yield, quality, shelf life etc. 


\section{Growth regulators in litchi}

In litchi, it is worthwhile to understand the certain basic concepts regarding the use of growth regulators. Physiological changes or abnormalities such as heavy fruit drop or early abscission in litchi might be due to the lack of hormones needed for the embryo and fruit development, lack of pollination and/or fertilization etc. All these can be dealt with effectively by understanding the concepts behind the use of different PGRs being used worldwide in litchi at different stages of growth and development.

\section{Auxins}

Chen (1990) investigated endogenous growth substances present at different stages viz leaf expansion, dormant bud (when apical leaves drop), 30 days before flower bud formation, flower bud formation and full bloom in litchi cv Heh Yeh and found that a constant level of IAA was maintained throughout all the five stages. Stern et al., (2001) concluded that the most suitable time, amount and stage of application of auxins was $0.5 \mathrm{~g}$ with $15 \mathrm{~mm}$ length or 3 weeks after pollination for litchi cv Kaimana, 1-2 g with 22-24 cm length or 4 weeks after pollination for Floridian and $2 \mathrm{~g}$ with 22-24 $\mathrm{mm}$ in length or 5 weeks after pollination for Mauritius. Synthetic auxins reduced fruit drop and increased the yield of litchi cultivars Mauritius and Kaimana up to 130 to 170 per cent, respectively when applied to trees soon after fruit set (Stern and Gazit, 1997 and 1999). 2,4,5-TP@67 ppm and 3,5,6-TPA@ 50 ppm have were found to increase the number of fruits per tree, doubled the fruit yield, increased fruit size and enhanced the red colour of ripe fruit of 'Fei $\mathrm{Zi}$ Xiao' and 'Hei Ye' litchi trees (Stern et al., 2001). Similar results were obtained by Sarkar et al., (1984 b). Drinnan (2014) found that 3,5,6-TPA@50 ppm as foliar spray to the litchi cultivars 'Fay Zee Siu', 'Kaimana', 'Kwai Mai Pink', 'Souey Tung' and 'Tai So' reduced the fruit drop and increased the fruit size when applied to fruit greater than $12 \mathrm{~mm}$ in length but increased fruit drop when fruit were smaller. According to Kumar et al., (2009), the highest aril percentage individual fruit weight per tree and number of fruits per tree was recorded in litchi trees of cv Purbi sprayed with 2,4-D @ 10 ppm.

Three sprays of NAA @ 20 ppm (at prebloom, completion of fruit set and before colour break stage) on litchi cv China resulted in least fruit cracking as compared to NAA @ $10 \mathrm{ppm}$ application (Rani and Brahmachari, 2001b). NAA @ 2.5 ppm registered highest initial fruit set (74.25 fruits/ panicle) in litchi cv. Dehradun and 5 ppm NAA registered highest TSS (19\%) and ascorbic acid content with increased with 100 ppm NAA. Same findings were registered by Singh and Phogat (1983); Anand et al., (2003) and in litchi cv Calcuttia (Sharma et al., 2005). Cuttings of litchi when immersed in 2000 or $5000 \mathrm{ppm}$ IBA, $2000 \mathrm{ppm} \mathrm{IBA} \mathrm{+} 150 \mu \mathrm{g} \mathrm{B} / \mathrm{ml}, 1500$ ppm NAA, Q-Muda (0.5\% IBA), Nafusaku $(0.5 \%$ NAA) or water, before placing in vermiculite trays showed that the per cent survival, percentage formation of callus, and root formation was the best after 120 days with commercial powder Q-Muda having 0.5 per cent IBA (Leonel et al., 1994). Sinha and Ray (2002) treated the ringed portion of litchi cv Bombai with 5000 ppm IBA, 5000 ppm IBA+200 ppm p-hydroxyl benzoic acid (PHB), 5000 ppm NAA+200 ppm PHB, 5000 ppm IBA+5000 ppm NAA and 5000 ppm NAA to see their effect on rooting and survival and observed that the highest rooting percentage, number of roots and maximum survival percentage of layers was obtained with 5000 ppm NAA + 200 ppm PHB treatments. Ray and Takawale (2013) studied the rooting behavior of eight litchi cultivars namely, Muzaffarpur, Nafarpal, Elaichi, Bombai, Purbi, Bedana, Rose Scented and China with the treatment of NAA @ 5000 ppm + PHB 200 ppm and IBA 5000 ppm + 
PHB 200m ppm against control and found that maximum mean number of roots per layer were recorded with $\mathrm{NAA}+\mathrm{PHB}$ treatment while maximum root length was recorded with $\mathrm{IBA}+\mathrm{PHB}$ treatment in all the cultivars.

\section{Cytokinins}

In pericarp of litchi in many cultivars (Erdanli, Huaizhi and Feizixiao), it was observed that the concentration of cytokinins was high in early blooms and a high CTK: ABA ratio favoured fruit growth in all cultivars of litchi (Li et al., 2005). Chen (1990) found highest levels of cytokinins in Heh Yeh cv of litchi trees in the xylem sap which reached maximum during flower bud formation and full bloom. O'hare and Turnbull (2004) observed that the concentration of a cytokinin, Zeatin Riboside in potted plants of litchi cv 'Tai so' kept at different temperatures increased to maximum in terminal buds just prior to shoot emergence and its exogenous application to dormant buds could initiate the bud break. According to Mishra et al., (2012), the application of BA (benzyl adenine) @ 40 ppm was the best treatment to delay the fruit maturity, and in terms of increase in ascorbic acid content in litchi cv Rose Scented. Stern et al., (2006) observed that application of synthetic cytokinin N-(2-chloro-4-pyridyl)-N'phenylurea (CPPU) @ 5-10 mg/l to green or slightly red fruitlets of litchi cv Mauritius delayed the harvesting by 2-3 weeks as compared to control and the fruits were more red in colour with $20-25 \%$ more size, higher TSS: acid ratio and could be stored well for 6 weeks due to reduced browning.

\section{Gibberellic acid}

According to Chen (1990), gibberellin content in litchi cv Heh Yeh was found to be high in xylem sap at stage of leaf expansion and came to a low level 30 days before flower bud formation and during flower bud formation. Interaction between borax $0.4 \%$ and $\mathrm{GA}_{3} 20$ ppm exhibited maximum fruit retention and fruit yield in litchi cv Ambika Litchi-1 (Dixit et al., 2013). Kumar et al., (2009) concluded that 20 ppm $\mathrm{GA}_{3}$ produced maximum number of fruits per tree, maximum weight of individual fruit and highest fruit yield in litchi cv Purbi in districts of Bihar. Maximum fruit weight and highest aril percentage were obtained with GA 100 ppm in litchi cv China (Rani and Brahmachari, 2001b). The fruits of litchi cv Purbi when sprayed at pea stage and 21 days later with $\mathrm{GA}_{3} @ 50,100$ and 150 ppm showed maximum fruit length, diameter, weight and volume with $50 \mathrm{ppm} \quad \mathrm{GA}_{3}$ application (Brahmachari et al., 1996).

Mishra et al., (2012) obtained minimum fruit cracking, maximum TSS and total sugars when the trees of litchi cv Rose Scented were sprayed with $\mathrm{GA}_{3} @ 40 \mathrm{ppm}$. In order to increase the fruit weight of shriveled seed cultivar 'Yu Her Pau' litchi, gibberellic acid was sprayed @ 5 and 10 mg/l 14 days after full bloom and was concluded that both the concentrations of $\mathrm{GA}_{3}$ significantly increased the fruit diameter, fruit weight, aril and pericarp weight over control (Chang and Lin, 2006).

The fruits of litchi cv Rose Scented when dipped in $200 \mathrm{ppm}$ solution of $\mathrm{GA}_{3}$ for two minutes and then stored at $5^{\circ} \mathrm{C}$ showed minimum physiological loss in weight and spoilage, resulting in increased shelf life of fruits to 5 days than control (Nigam et al., 2001). Chen et al., (2014) studied the effect of $\mathrm{GA}_{3} @ 100$ ppm applied foliarly to litchi cv 'Yu Her Pau' and found that it significantly increased the average number of fruits per branch and ultimately the yield. While same concentration in combination with kinetin (25 ppm) sprayed to the trees of litchi cv Bombai at aril development stage delayed the fruit ripening by about 4 days along with improvement in fruit (Dhua et al., 2005). 


\section{Ethephon}

Olesen et al., (1999) concluded that ethephon could be used to control early red leaf flushes in litchi when applied in May or June resulting in emergence of new buds behind the damaged shoots within a few weeks and it had the advantage of easy application as compared to mechanical pruning. Ethephon @ $2500 \mathrm{ppm}$ resulted in promotion of fruit ripening and colouration in litchi by improving the anthocyanin levels in the peel and increased TSS, sugars, ascorbic acid and decreased acidity in pulp (Sadhu and Chattopadhyay, 1989) while ethrel @ 800 $\mathrm{mg} / \mathrm{l}$ at colour break was responsible for highest anthocyanin levels in litchi cv Nuomici (Wang et al., 2007). According to Mandal et al., (2014), among paclobutrazol @ 2 and $3 \mathrm{ml}$ a.i. $/ \mathrm{m}^{2}$ canopy, ethrel 1 and $2 \mathrm{ml} / 1$ and cincturing in Sept-Oct, application of ethrel @ $2 \mathrm{ml} / \mathrm{l}$ was the most effective for flower and fruit induction in litchi cv Bombai, earlier reported in litchi cv 'Hong Huay' by Subhadrabandhu and Duang (1987), but it failed to promote flowering after reducing the flower number in variety Ouxia of litchi, in contrary to previous results. Li et al., (1992) reported that application of ethephon inhibited the germination of winter shoots for 22-27 days in Baila, Heiye and Guiwei litchi and its spray at flower bud differentiation reduced the flower number on each panicle improving fruit quality. Flowering of 'Sijimi' was induced by $75 \mathrm{mg} / \mathrm{L}$ PP333 + $142.8 \mathrm{mg} / \mathrm{L}$ ethrel during young shoots turning green, by $37.5 \mathrm{mg} / \mathrm{L}$ PP333 and $142.8 \mathrm{mg} / \mathrm{L}$ ethrel during terminal bud germination, and by 25.5 mg/L PP333 during flushing (Zhu et al., 2011). Xu et al., (2011) found $233 \mathrm{mg} / \mathrm{L}$ ethephon $+90 \mathrm{mg} / \mathrm{L}$ paclobutrazol, or 300 $\mathrm{mg} / \mathrm{L}$ ethephon $+90 \mathrm{mg} / \mathrm{L}$ paclobutrazol to be more effective in preventing leafy panicles and encouraging for development of pure panicles in 'Shixia' longan trees when sprayed at the panicle emergence. Mahajan and Sharma (1995) found that ethrel@ $@ 500$ ppm was the most effective in improving the fruit quality and hastening the ripening in litchi cv Dehradun. According to Diao (2006), ethephon $(0.05$ to $0.06 \%)$ in combination with paclobutrazol $(0.05 \%)$ on litchi trees had inhibitory effect on shoot tip growth and could reduce number of male flowers and the nutrient consumption of the tree. In a survey, it was observed that high concentration of ethephon $(700 \mathrm{mg} / \mathrm{kg}$ or above) when sprayed on litchi trees might cause phytotoxicity, while leaf abscission rate decreased with the reduction of its concentration ( $\mathrm{Yu}, 2008)$. Tang (2006), in his study concluded that combined spray of ethephon at higher concentration $(800 \mathrm{mg} / \mathrm{l})$ and paclobutrazol in lower concentration $(400 \mathrm{mg} / \mathrm{l})$ could remarkably reduce the contents of IAA and $\mathrm{GA}_{3}$ in Jizui litchi while ABA was increased resulting in improved flower formation. Similar results were reported by Mitra and Sanyal (2000). Sharma et al., (1986) reported the hastening of maturation by ethrel treatment 3 weeks before harvesting in litchi cv Shashi.

\section{Abscissic acid}

Chen (1990) observed an increase in ABA level 30 days before bud formation in litchi $\mathrm{cv}$ Heh Yeh and concluded that the decrease in shoot growth was associated with high ABA content. Pre-harvest exogenous application of ABA @ 150 ppm and 300 ppm at colour break stage in litchi cv Calcuttia significantly increased the accumulation of anthocyanins in litchi pericarp without adversely affecting the post harvest quality (Singh et al., 2014). Wang et al., (2007) investigated changes in endogenous abscissic acid levels during the course of fruit development and maturation in litchi cvs. Feizixiao and Nuomici and found that ABA concentration in aril as well as pericarp of litchi went on increasing with the fruit maturation and it was critical for sugar 
accumulation in the fruit while its exogenous application promoted the anthocyanin synthesis. Exogenous ABA treatment @ 100 $\mu \mathrm{mol} / \mathrm{l}$ to the fruits of litchi cv Guiwei and then storage at $0 \pm 2^{\circ} \mathrm{C}$ effectively, delayed colour change to red, decreased the anthocyanin content of the fruit and reduced the activity of polyphenol oxidase and hence retarded the development of pericarp browning resulting in more chilling tolerance of the fruits (Hu et al., 2010).

CCC: A dose of $2000 \mathrm{ppm}$ resulted in maximum pulp weight, pulp/stone ratio, TSS and minimum acidity whereas CCC 500 ppm was found to be sig

nificantly effective in decreasing seed weight as well as peel weight in Calcuttia cv of litchi (Singh et al., 2012). Fruits of litchi cv China sprayed with CCC $500 \mathrm{ppm}$ resulted in highest TSS, total sugars, ascorbic acid and least acidity (Rani and Brahmachari, 2001b). According to Thakur et al., (1990), CCC @ $2000 \mathrm{ppm}$ significantly improved the fruit set, fruit size and retention in litchi cvs. Purbi and DeshiIn experiments on litchi cv Purbi, the spray of CCC @ 300 ppm at pea stage and again 21 days later resulted in minimizing the fruit drop as compared to other treatments (Brahmachari et al., 1996).

\section{Paclobutrazol}

Singh et al., (2012) found that PBZ @ $7.5 \mathrm{~g}$ per tree was the most effective treatment for suppressing shoot growth, panicle size, male flower percentage, fruit drop and increased the hermaphrodite percentage, sugars, fruit size and fruit yield per tree in litchi cv Calcuttia. Singh et al., (2017) applied PBZ @ $1,2,3$ and $4 \mathrm{~g}$ a.i. per meter tree canopy as soil drenching along with combination of two levels of potassium nitrate @ 100 and 200 $\mathrm{mg} / \mathrm{l}$ respectively as triple application starting from 3 months after harvesting of the fruit at 15 days interval on trees of litchi cv China and observed the significant reduction in vegetative winter flushing and more floral shoots as compared to control. In 'Bengal' litchi trees, Pires and Yamanishi (2014) applied PBZ at 500, 1000 and $2000 \mathrm{mg}$ a i/m of canopy diameter of the tree in May soon after girdling of main trunk, and branches. They concluded that tree trunk girdling combined with the application of PBZ @ $1000 \mathrm{mg}$ ai $/ \mathrm{m}$ of canopy diameter significantly increased the average yield by 4 to 6 folds as compared to control. Singh et al., (2017) found that the trees treated with PBZ @ $4 \mathrm{~g} \mathrm{a}$ i/ $\mathrm{m}$ canopy of tree proved to be the most significant as the number of vegetative flushing in winter was significantly reduced with 66 per cent emergence of floral branches. Hung and Nghi (2006) observed that in litchi cv Binhkhe PBZ applied @ 20 gm a $i /$ tree in late Aug-early Sept at mature bud stage resulted in the inhibition of winter bud emergence, reduced inflorescence size but increased female flowers, fruit set and yield by 61.5-85.2 per cent than control.

\section{Maleic hydrazide}

Biao and Fang (1998) tried many growth regulators for inducing kernellessness or mini kernels in litchi cv Huaizhi and found $1 \mathrm{~mm}$ $\mathrm{MH}$ sprayed twice to be the most effective in obtaining mini kernelled/ aborted kernel fruits with 100\% success. Liang and Qiu (1998) applied Maleic Hydrazide @ 1000 mg/l about 2 weeks from full bloom in litchi cv. Huaizhi and concluded that fruit weight was same as non- sprayed fruits, but had shriveled seeds and about $10 \%$ more aril than untreated controls. Spraying PP333 or ethrel $+\mathrm{MH}$ to litchi flower clusters could extend the flowering period by 10-14 ultimately increasing the fruit production (Win et al., 1998).

In conclusion, important future perspective with researchers has been to test new 
formulations and adjuvants to increase the efficacy of the PGRs. The knowledge of application of specific hormones at proper phenological stage for effective manipulation of key physiological processes can result in more efficient management strategies and achieving the desired goals.

\section{References}

Anand, M., P.S. Kahlon and Mahajan, B.V.C. 2003. Effect of exogenous application of growth regulators on fruit drop, cracking and quality of litchi (Litchi chinensis Sonn.) cv Dehradun. Agri. Sci. Digest, 23(3): 191-194.

Annonymus. 2015. The Litchi scenario. NHB, Govt of India; http://nhb.gov.in/areapro/NHB_Database.

Biao, D.S. and Fang, G.X. 1998. Experiment on inducing kernellessness or minikernels in litchi varieties by using plant growth regulators. South China Fruits, 27 (4): 25.

Brahmachari, V.S., K. Lalduhawarna and Kumar, R. 1996 Effect of $\mathrm{GA}_{3}$ and growth retardants on fruit drop and fruit characteristics of litchi (Litchi chinensis Sonn.). Orissa J. Hort., 24(1): 5-9.

Chang, J.C. and Lin, T.S. 2006. GA increases fruit weight in 'Yu Her Pau' litchi. Scientia Horticulturae, 108: 442443.

Chen, P.A., C.L. Lee, S.F. Roan and Chen, I.Z. 2014. Effects of $\mathrm{GA}_{3}$ application on the inflorescence and yield of 'Yu Her Pau' litchi. Scientia Horticulturae, 171: 45-50.

Chen, W.S. 1990. Endogenous growth substances in xylem and shoot tip diffusate of lychee in relation to flowering. Hort. Sci., 25(3): 314-315.

Dhua, R.S., R. Roychoudhury and Kabir, J. 2005. Staggering the lychee fruit harvest. Acta Hort., 665: 347-354.

Diao, Z.C. 2006. The application of chemistry regulation technology in management of litchi in autumn and winter. Yunnan Forestry, 27(5): 27-28.

Dixit, A, S.S. Shaw and Pal, V. 2013. Effect of micronutrients and plant growth regulators on fruiting of litchi. Hortflora Res. Spectrum, 2(1): 77-80.

Drinnan, J. 2014. The Effect of 3-5-6 TPA on Fruit Drop and Fruit Size in the Lychee (Litchi chinensis) Cultivars 'Fay Zee Siu' ('Feizixiao'), 'Kaimana', 'Kwai Mai Pink', 'Souey Tung' and 'Tai So' ('Mauritus'). Acta Hort., 1029, ISHS, pp 273-280.

Hu, W.R., Liu, S.Z., Pang, X.Q., Ji, Z.L. and Zhang, Z.Q. 2010. Alleviation of chilling injury in litchi fruit by ABA application. Proc. 3rd IS on Longan, Lychee \& Other Fruit Trees in Sapindaceae Family. Acta Hort., 863: 533-538.

Hung, N.Q. and Nghi, D.Q. 2006. Effect of paclobutrazol on growth, flowering, fruit setting and yield of Binhkhe early litchi variety. Informatic Centre for Agriculture and Rural Development: http://www.agroviet.gov.vn/en/Pages/de fault.aspx

Jiang, J.P., M.X. Su and Lee, P.M. 1986. The production and physiological effects of ethylene during ontogeny and after harvest of litchi fruits. Acta Phytophysiol. Sin., 12: 95-103.

Kumar, M., R. Kumar and Singh, R.P. 2009. Effect of micronutrients and plant growth regulators on fruiting of litchi. Int. J. Agri. Sci., 5(2): 521-524.

Leonel, S., J.D. Rodrigues and Cereda, E. 1994. Action of growth regulators and boric acid on litchi (Litchi chinensis Sonn.) cuttings. Cientifica (Jaboticabal) 22(1): 105-110.

Liang, Y.G. and Qiu, S.D. 1998. A study on the artificially inducing techniques from large seeded fruit to small seeded and high quality fruit in lychee (Litchi 
chinensis Sonn.). XXV Int Hort Cong, Brussels, p 355.

Li, H.Z., J.S. Luo and Zhang, Y.Y. 1992. Experiment on spraying ethephon to control winter shoots of litchi tree. China Fruits, 3: 26-28.

Li, J.G., B.Y. Zhou, Huang, X.M. and Huang, H.B. 2005. The roles of cytokinins and abscissic acid in the pericarp of litchi (Litchi chinensis Sonn.) in determining the fruit size. J. Hort. Sci. Biotech., 80(5): 571-574.

Mahajan, B.V.C. and Sharma, R.C. 1995. Effect of pre-harvest application of ethrel on the quality and ripening of litchi. Agric. Sci. Dig., 15: 231-234.

Mandal, D., A. Sarkar and Ghosh, B. 2014. Induction of flowering by use of chemicals and cincturing in 'Bombai' litchi. Acta Hort., 1029: 265-271.

Mishra, D.S., P. Kumar and Kumar, R. 2012. Effect of $\mathrm{GA}_{3}$ and BA on fruit weight, quality and ripening on 'Rose Scented' litchi. Hortflora Res. Spectrum, 1(1): 80-82.

Mitra, S.K. and Sanyal, D. 2000. Effect of cincturing and some chemicals on flowering of litchi cv. Bombai. Acta Hort., 508: 243-246.

Nigam, J.K., G. Kumar and Misra, K.K. 2001. Effect of wax coating and gibberellic acid treatment on shelf life of litchi (Litchi chinensis Sonn.) fruits. Progressive Horticulture, 33(1): 49-51.

O'hare, T.J. and Turnbull, C.G.N. 2004. Root growth, cytokinin and shoot dormancy in lychee (Litchi chinensis Sonn.). Scientia Horticulturae, 102: 257-266.

Olesen, T., C.M. Menzel, N. Wiltshire and McConchie, C.A. 1999. Manipulating flushing cycles and flowering in lychee. Proceedings of the Fifth National Lychee Conference, Twin Waters. pp. 47-52.

Pandey, R.M. and Sharma, H.C. 1989. The Litchi. Indian Council of Agricultural
Research publication, New Delhi.

Pires, M.C. and Yamanishi, O.K. 2014. Girdling combined with paclobutrazol boosted yield of 'Bengal' lychee in Brazil. Acta Hort., 1042: 189-195.

Rani, R. and Brahmachari, V.S. 2001b. Effect of plant bioregulators on cracking and physico-chemical composition of fruit in china litchi. Prog Hort 33 (1): 32-36.

Ray, S.K.D. and Takawale, P. V. 2013. Root characteristics of air layer of different litchi varieties (Litchi chinensis Sonn.) as influenced by growth regulators. $J$. Interacademicia, 17(3): 418-423.

Sadhu, M.K. and Chattopadhyay, G. 1989. Effect of post-harvest fruit dip in ethephon on the ripening of litchi fruits. J. Hort. Sci., 64(2): 239-242.

Sarkar, G.K., M.M. Sinha and Mishra, R.S. 1984b. Effect of NAA on fruit set, fruit drop, cracking, fruit size and quality in litchi cv Rose Scented. Prog. Hort., 16(3-4): 301-304.

Sharma, P., A.K. Singh and Sharma, R.M. 2005. Effect of plant bio-regulators and micronutrients on fruit set and quality of litchi cv. Dehradun. Indian J. Hort. 62(1): 24-26.

Sharma, S.B., P.K. Ray and Rai, R. 1986. The use of growth regulators for early ripening of litchi (Litchi chinensis Sonn). J. Hort. Sci., 61: 533-534.

Singh, B., S. Singh and Sandhu, S. 2012. Effect of growth retardants on vegetative growth, flowering and fruiting of litchi cv. Calcuttia. Hortflora Res. Spectrum, 1(1): 29-33.

Singh, O.P. and Phogat, K.P.S. 1983. Effect of growth regulators on fruit drop, size and quality of litchi cv Calcuttia. Punjab Hort. J., 13: 83-88.

Singh, S.K., A. Kumar, S.D. Pandey and Nath, V. 2017. Physio-biochemical status of shoots related to litchi flowering. Int. J. Adv. Biol. Res., 7(1): 185-189. 
Singh, S.P., M.K. Saini, J. Singh, A. Pongener and Sidhu, G. 2014. Preharvest application of abscissic acid promotes anthocyanins accumulation in pericarp of litchi fruit without adversely affecting postharvest quality. Postharvest Biol. Technol., 96: 14-22.

Sinha, R. and Ray, S.K.D. 2002. Effect of different growth regulators in air layering of litchi cv Bombai. Hort. J., 15(1): 63-67.

Stern, R.A. and Gazit, S. 1997. Effect of 3,5,6-trichloro 2-phyridyl-oxyacetic acid on fruitlet abscission and yield of Mauritius litchi. J. Hort. Sci., 72(4): 659-663.

Stern, R.A. and Gazit, S. 1999. The synthetic auxin 3,5,6-TPA reduces fruit drop and increases yield in Kaimana litchi. $J$. Hort. Sci. Biotech., 74(2): 203-205.

Stern, R.A., O. Nerya and Ben, A.R. 2006. The cytokinin CPPU delays maturity in litchi cv "Mauritius" and extends storage life. J. Hort. Sci. Biotech., 81(1): 158-162.

Stern, R.A., D. Stern, H. Miller, H. Xu and Gazit, S. 2001. The effect of synthetic auxins 2,4,5-TP and 3,5,6-TPA on yield and fruit size of young 'Fei $\mathrm{Zi} \mathrm{Xiao'}$ and 'Hei Ye' litchi trees in Guangxi province, China. Acta Hort., 558: 285288.

Subhadrabandhu, S. and Duang, K.A. 1987. Effect of ethephon on flowering of two lychee (Litchi chinensis Sonn.) cultivars. Acta Hort., 201: 181-186.

Tang, Z.P. 2006. Effect of ethrel and PP333 on endogenous hormones and flower bud differentiation of Jizui litchi. $J$. Human Agri. Univ., 32(2): 135-140.

Thakur, S., R. Kumar, V.S. Brahmachari and Sharma, R.K. 1990. Effect of different growth regulators on fruit set, retention and size of litchi. Ind. J. Hort., 47(3): 305-308.

Wang, H., H. Huang and Huang, X. 2007. Differential effects of abscissic acid and ethylene on the fruit maturation of Litchi chinensis Sonn. Plant Growth Regul., 52: 189-198.

Win, Y.J., L.Y. Min and Zhu, W.B. 1998. Effect of plant growth regulators on the production of litchi trees. South China Fruits, 27(1): 27.

Xu, N.J., H. Zhu, H.X. Peng, G.W., Li, F.Z. Huang and Li, D.B. 2011. Effects of ethephon and paclobutrazol preventing longan spring inflorescence with branch leaves. $44^{\text {th }}$ Chinese Agric. Sci. Bull., 27(6): 197-200.

$\mathrm{Yu}$, M.X. 2008. Experiment on applying ethephon to control winter shoots and promote flowering of litchi tree. Guangxi Horticulture, 19(3): 50.

Zhu, J.H., F.Z. Huang, N. Xu, H.X. Peng and Lu, G. 2011. A study on flowering regulation of Dimocarpus longan 'Sijimi'. Chinese Agric. Sci. Bull., 27(25): 283-293.

\section{How to cite this article:}

Rachna Arora and Nav Prem Singh. 2017. Growth Regulators for Yield and Quality Enhancement in Litchi (Litchi chinensis L) - A Review. Int.J.Curr.Microbiol.App.Sci. 6(8): 2152-2159. doi: https://doi.org/10.20546/ijcmas.2017.608.255 